\title{
The steam gasification of coal with molten blast furnace slag as heat carrier and catalyst: Kinetic study
}

Wenjun Duan*, Qingbo Yu, Tianwei Wu, Fan Yang, Qin Qin

School of Metallurgy, Northeastern University, No 11, Lane 3, Wen Hua Road, He

Ping District, Shenyang 110819, Liaoning, People's Republic of China.

*Corresponding author information:

Telephone/Fax: +86-024-83672216.

E-mail addresses: duanwenjn@163.com (W. J. Duan)

$$
\text { yuqb@smm.neu.edu.cn (Q. B. Yu) }
$$

Mailing address: P.O, Box 345, Northeastern University, No11, Lane 3, Wenhua Road, Heping District, Shenyang, Liaoning, P. R. China. 


\section{Abstract}

In this study, we carried out a kinetic investigation to analyze the steam gasification of FS (Fu Shun) coal. The effect of reaction temperature $(1573 \mathrm{~K} \sim 1673 \mathrm{~K})$ was studied, and the coal/slag ratios were in the range of 1:0 1:2. The reaction temperature and coal/slag ratio affected the carbon conversion and reactivity index of FS coal gasification. With reaction temperature increasing, the time for carbon conversion completing decreased. But the effect of temperature was non-significant, when it was above $1623 \mathrm{~K}$. The reactivity index of coal at $1673 \mathrm{~K}$ was about 1.6 times faster than that at $1573 \mathrm{~K}$, when the coal/slag ratio was 1:0. The BFS (blast furnace slag) acted as not only a heat carrier but also an effective catalyst in steam gasification. Compared with the steam gasification of "pure" FS coal, both carbon conversion and reactivity index of gasification were enhanced by BFS. Meanwhile, the Diffusion model ( $\mathrm{D}_{1}$ model) and Shrinking core model $\left(\mathrm{R}_{2}\right.$ model) were proved as the most appropriate model to describe the steam gasification without and with BFS as heat carrier, respectively. The kinetic parameters applicable to the established model with different coal/slag ratios were obtained. Under these conditions, the valid range of activation energy for gasification reaction was $20 \mathrm{~kJ} \cdot \mathrm{mol}^{-1} \sim 64 \mathrm{~kJ} \cdot \mathrm{mol}^{-1}$.

\section{Keywords:}

Coal; Steam gasification; Molten blast furnace slag; Kinetic model; Carbon conversion 


\section{Introduction}

"Hydrogen energy economy" had a significant merit to reduce global $\mathrm{CO}_{2}$ emissions [1]. At present, $96 \%$ of the total $\mathrm{H}_{2}$ production was contributed by fossil fuels [2]. However, the fossil fuels caused numerous environmental problems, such as greenhouse effect, huge energy consumption, ozone layer depletion and acid rain [3]. Therefore, producing the sufficient $\mathrm{H}_{2}$ economically and environmentally friendly was a major challenge.

In face of this challenge, Liu [4] proposed the theory of coal gasification reaction with molten BFS as heat carrier to produce hydrogen-rich syngas. Based on this theory, an attempt was made by Duan [5-10] to explore the potential of hydrogen-rich syngas production and waste heat recovery of slag. Li and $\mathrm{Yu}$ et al [11-15] also carried on the thorough research in the aspect of gasification and waste heat recovery. They found that the BFS provided the energy needed for gasification reaction, while the higher content of hydrogen in the syngas was obtained. Luo $[16,17]$ used the BFS waste heat to generate hydrogen-rich gas in a continuous moving-bed biomass gasification reactor. When temperature of BFS was $1473 \mathrm{~K}$ and its size was below 2 $\mathrm{mm}$, the gas yield and $\mathrm{H}_{2}$ content achieved the maximum of $1.28 \mathrm{Nm}^{3} \cdot \mathrm{kg}^{-1}$ and $46.54 \%$, respectively. The integrated $\mathrm{CO}_{2} /$ sludge gasification using the slag waste heat was explored by Sun et al $[18,19]$. The gas yield reached to $0.422 \mathrm{~kg} \cdot \mathrm{kg}_{\text {sludge }}{ }^{-1}$ at $773 \mathrm{~K}$, and the $\mathrm{SO}_{2}$ reduced to $114 \mathrm{ppm}$ at $1173 \mathrm{~K}$. 
The steam gasification of coal was a process for utilizing the energy in coal resources, without the traditional combustion process [20]. Sedghkerdar et al [21] investigated the $\mathrm{CO}_{2}$ capture and $\mathrm{H}_{2}$ production during the steam gasification using a horizontal fixed reactor. The maximum fraction of $\mathrm{H}_{2}(81.7 \%)$ and minimum $\mathrm{CO}_{2}$ concentration (almost $0 \%$ ) were obtained at $948 \mathrm{~K}$. The experiments of $\mathrm{H}_{2}$ production by coal gasification in supercritical water was conducted by Jin [22]. The carbon gasification efficiency was $95.7 \%$, and the hydrogen yield was $42.22 \mathrm{~mol} \cdot \mathrm{kg}^{-1}$. Phuhiran $\mathrm{C}$ [23] carried out the experiment of $\mathrm{H}_{2}$ production by catalytic steam gasification. The highest $\mathrm{H}_{2}$ fraction and the maximum $\mathrm{H}_{2} / \mathrm{CO}$ ratio reached to $46.68 \%$ and 1.24 at $923 \mathrm{~K}$, respectively.

As the research progressed, the kinetic analysis of steam gasification had been ever the subject of previous studies [24-29]. Jin [25] developed a novel kinetic model concentrating on gas species by lignite gasification in supercritical water. The model could be a useful tool for predicting the gas yield and the clarifying the mechanism. Kim [28] proposed a kinetic model of steam gasification of Ca-loaded lignite char. The model quantitatively described the change of the char conversion within the whole time range, all of gasification reactions obeyed Langmuir-Hinshelwood mechanisms. Jang [29] investigated the kinetic experiments in order to achieve the SNG production. In his study, the basic model was selected and limited kinetic values, and equations were applied. The model for catalytic coal gasification was executed about another different coal and it could obtain the result in the syngas composition 
which could be compared with the basic model.

From the above researches, the kinetic investigation of the steam gasification was benefited to control the reaction process. However, there was no kinetic study for steam gasification of coal with molten BFS as heat carrier. Although Li et al $[14,15]$ established the kinetic model of coal- $\mathrm{CO}_{2}$ gasification with molten BFS as heat carrier, there still was significant difference of the coal reactivity between steam gasification and $\mathrm{CO}_{2}$ gasification, which would result in various differences in design and operation of the coal gasifier. Therefore, it was necessary to conduct the detailed and systematic research on steam gasification of coal with molten BFS as heat carrier.

In present paper, the isothermal steam gasification of coal with molten BFS as heat carrier was systematically investigated using thermo-gravimetric method. The effect of temperature and coal/slag ratio on the carbon conversion and reactivity index were obtained. Furthermore, the steam gasification of coal was simulated using typical kinetic models. The inherent kinetic parameters of steam gasification were obtained and the most appropriate model was established.

\section{Methods and mechanism}

\subsection{Experimental apparatus and procedure}

A SETSYS Evolution TGA coupled with a Wetsys was used to perform atmospheric steam gasification reaction in molten BFS. The schematic diagram of the experimental apparatus was presented in Fig. 1. In experiment, the sample was hung 
below an electronic balance by suspension wire, and the weight loss of sample was recorded by the balance. The gas flowed in the reactor to form the circulation reaction area, and then flowed out after the reaction completing. Ar stream was adopted as a protective gas and controlled with a flowmeter. The steam stream was controlled and heated to $308 \mathrm{~K}$ by Wetsys. At last, the reaction gas of steam and Ar were adopted in the thermo-gravimetric experiment.

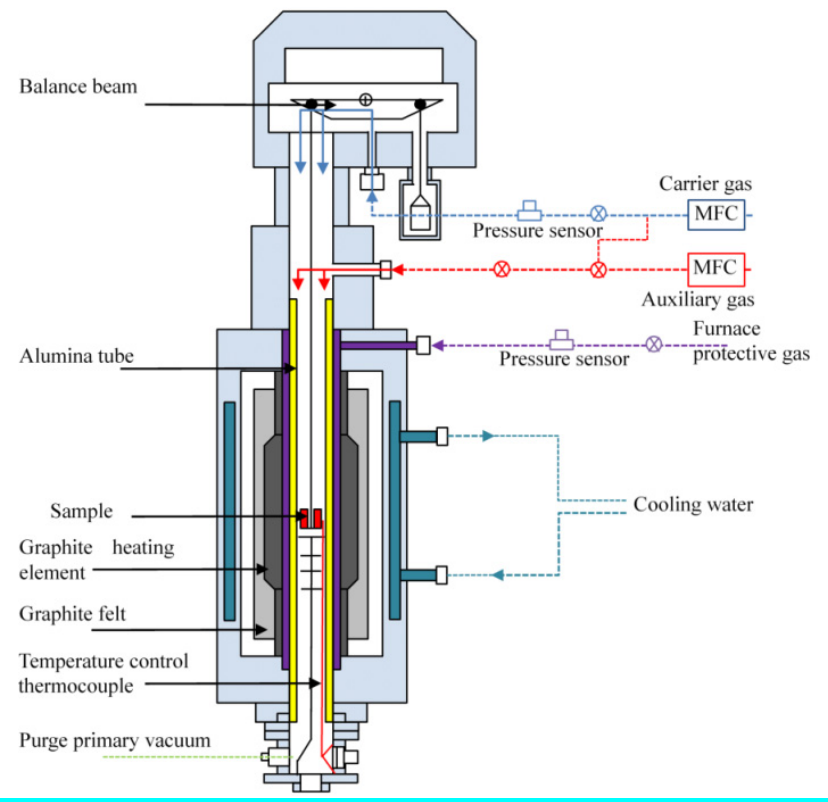

Fig. 1 The schematic diagram of the thermo-gravimetric experimental apparatus

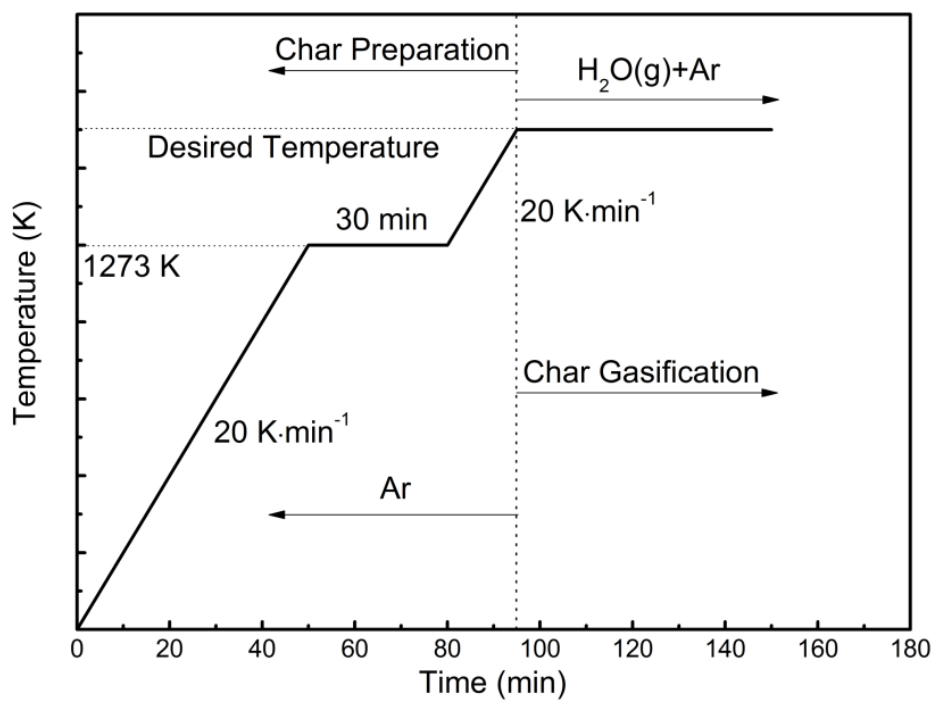


Fig. 2 The diagram of the thermo-gravimetric experimental procedure

In experiment, the coal sample mixed with/without BFS $(\sim 10 \mathrm{mg})$ was placed in alundum crucible $(\Phi 5 \times 4 \mathrm{~mm})$ and $\operatorname{Ar}$ stream flowed through the balance at 50 $\mathrm{mL} \cdot \mathrm{min}^{-1}$ as the protective gas. As shown in Fig. 2, the coal char preparation and gasification proceeded consecutively in the thermo-gravimetric analyzer. The sample was pyrolyzed by heating it to $1273 \mathrm{~K}$ at $20 \mathrm{~K} \cdot \mathrm{min}^{-1}$ in $\mathrm{Ar}$ atmosphere. The sample was maintained at $1273 \mathrm{~K}$ for $30 \mathrm{~min}$ to complete the pyrolysis. After it, the sample was heated to the desired temperature $(1573 \mathrm{~K}, 1623 \mathrm{~K}$ and $1673 \mathrm{~K})$ at $20 \mathrm{~K} \cdot \mathrm{min}^{-1}$ in Ar atmosphere. Then, the steam mixed with Ar was flowed into the reactor to complete the coal gasification in molten BFS. The total gas flow was $50 \mathrm{~mL} \cdot \mathrm{min}^{-1}$, and the relative humidity was controlled at $75 \%$. The gasification reaction continued for $60 \mathrm{~min}$ to ensure the reaction running completely. The mass of the sample could be measured by the thermo-gravimetric analyzer and recorded by a computer.

\subsection{Sample characterization}

Fu Shun (FS) coal was utilized in this kinetic study. FS coal sample with particle size about $75 \mu \mathrm{m}$ was prepared to ensure that the intrapore diffusion did not control the coal gasification rate [30-32]. The ultimate analysis of the sample was conducted using a CHNS/O Analyzer, Perkin Elmer PE 2400 series II. The proximate analysis of the sample was performed at atmospheric pressure using a auto-measuring industrial analyzer, SUNDY SDTGA 5000 according to the ASTM Standard Methods (ASTM D 5142-90, ASTM D 5373-93 and ASTM D 6349-98) for coal. The proximate 
analysis and ultimate analysis of FS coal sample were shown in Table1.

Table 1 The proximate and ultimate analysis of FS coal sample

Proximate analysis (wt, \%)

\begin{tabular}{|c|c|}
\hline Moisture & 1.83 \\
\hline Volatile matter & 28.72 \\
\hline Fixed carbon & 20.81 \\
\hline Ash & 48.64 \\
\hline \multicolumn{2}{|c|}{ Ultimate analysis (wt, \%) } \\
\hline $\mathrm{C}$ & 39.05 \\
\hline $\mathrm{H}$ & 3.489 \\
\hline $\mathrm{N}$ & 1.13 \\
\hline $\mathrm{S}$ & 0.619 \\
\hline \multirow[t]{2}{*}{$\mathrm{O}$} & 5.242 \\
\hline & Heating value analysis $\left(\mathrm{MJ} \cdot \mathrm{kg}^{-1}\right)$ \\
\hline Lower heating value (LHV) & 16.29 \\
\hline
\end{tabular}

In addition, the water quenched BFS supplied by a factory was used as heat carrier and catalyst. To confirm the glassy phase of the quenched slags, XRD (X-ray diffraction) analysis was carried out, as shown in Fig. 3. The XRD test was performed in a $2 \theta$ degree range of $10^{\circ}-70^{\circ}$ with a speed of $4^{\circ} \cdot \mathrm{min}^{-1}$, where $\theta$ was the angle between the incident ray and the scattered plane and the intensity of the reflected ray 
was shown in Y-axis. The chemical compositions of BFS were analyzed by X-ray fluoroscopy (XRF, SE-Explore, Bruker). The physical properties and chemical compositions of BFS were given in Table 2. The BFS was grained and sieved to the same particle size with FS coal. Finally, the experimental samples were prepared with three coal/slag ratios as 1:0,1:1 and 1:2, respectively.

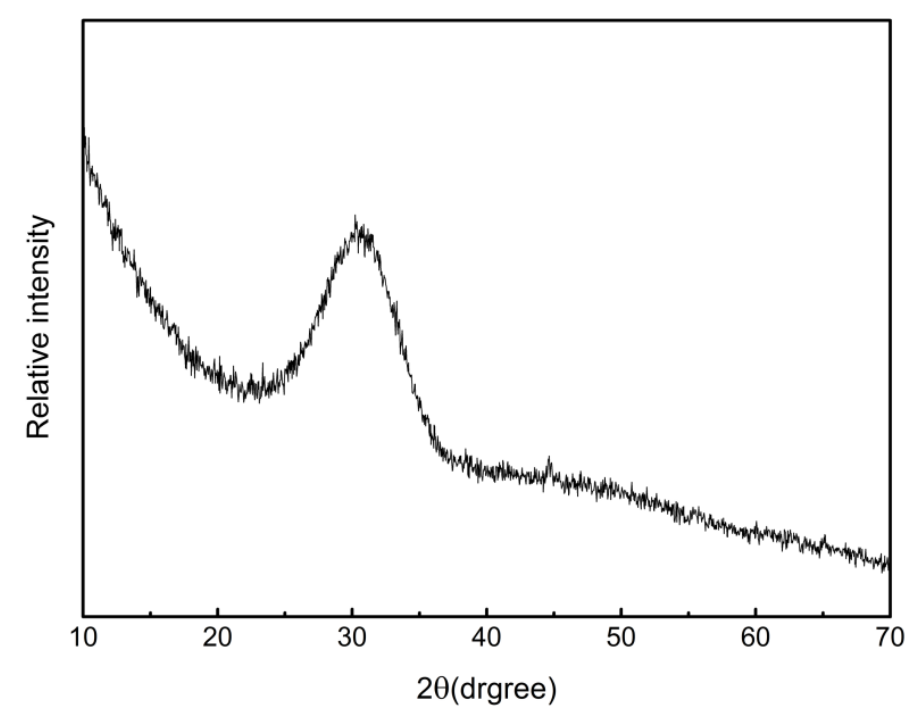

Fig. $3 \mathrm{XRD}$ results of the water quenched BFS

Table 2 The physical properties and chemical compositions of the BFS

\begin{tabular}{cc|cc}
\hline \multicolumn{2}{c|}{ Physical properties } & & \multicolumn{2}{c}{ Chemical compositions (wt, \%) } \\
\hline Molten slag density, $\left(\mathrm{kg} \cdot \mathrm{m}^{-3}\right)$ & $2.71 \times 10^{3}$ & $\mathrm{CaO}$ & 41.21 \\
Particle density, $\left(\mathrm{kg} \cdot \mathrm{m}^{-3}\right)$ & $2.80 \times 10^{2}$ & $\mathrm{MgO}$ & 8.22 \\
Bulk density, $\left(\mathrm{kg} \cdot \mathrm{m}^{-3}\right)$ & 950 & $\mathrm{SiO}_{2}$ & 34.38 \\
Melting point, $(\mathrm{K})$ & 1553 & $\mathrm{Al}_{2} \mathrm{O}_{3}$ & 11.05 \\
Energy level & 0.83 & $\mathrm{Fe}_{2} \mathrm{O}_{3}$ & 2.78 \\
Enthalpy (MJ) & 1573 & $\mathrm{TiO}_{2}$ & 0.35 \\
\hline
\end{tabular}




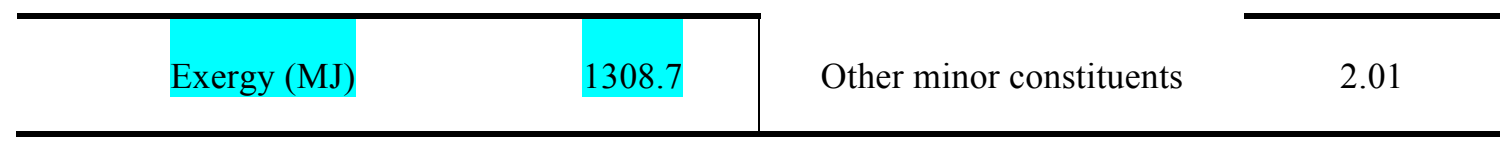

2.3 Gasification mechanism

The coal gasification reaction was a thermal-chemical process in which the solid fuels were converted to combustible gases by partial oxidization with steam. The results were interpreted by the following reversible chemical reactions which occurred in the coal gasification reaction [5, 33-35].

Boudouard reaction (BD)

$\mathrm{C}+\mathrm{CO}_{2} \leftrightharpoons 2 \mathrm{CO} ; \Delta H_{\mathrm{r}}=172 \mathrm{~kJ} \cdot \mathrm{kmol}^{-1}$

Methane formation reaction (MF)

$\mathrm{C}+2 \mathrm{H}_{2} \leftrightharpoons \mathrm{CH}_{4} ; \Delta H_{\mathrm{r}}=-75 \mathrm{~kJ} \cdot \mathrm{kmol}^{-1}$

Primary water gas reaction (PWG)

$\mathrm{C}+\mathrm{H}_{2} \mathrm{O} \leftrightharpoons \mathrm{CO}+\mathrm{H}_{2} ; \Delta H_{\mathrm{r}}=131 \mathrm{~kJ} \cdot \mathrm{kmol}^{-1}$

Methane reforming reaction (MR)

$\mathrm{CH}_{4}+\mathrm{H}_{2} \mathrm{O} \leftrightharpoons \mathrm{CO}+3 \mathrm{H}_{2} ; \Delta H_{\mathrm{r}}=206 \mathrm{~kJ} \cdot \mathrm{kmol}^{-1}$

Water gas shift reaction (WGS)

$\mathrm{CO}+\mathrm{H}_{2} \mathrm{O} \leftrightharpoons \mathrm{CO}_{2}+\mathrm{H}_{2} ; \Delta H_{\mathrm{r}}=-41 \mathrm{~kJ} \cdot \mathrm{kmol}^{-1}$

Meanwhile, there were some specific reactions occurred when the BFS existed in the process of coal gasification. It would have a significant impact on the gasification reaction rate and the composition of syngas [18, 19, 35].

$\mathrm{CaO}+1 / 2 \mathrm{O}_{2} \rightarrow \mathrm{CaO}_{2}$ 
$\mathrm{CaO}_{2}+\mathrm{C} \rightarrow \mathrm{CaO}+\mathrm{CO}$

$\mathrm{Fe}_{\mathrm{m}} \mathrm{O}_{\mathrm{n}}+\mathrm{CO}_{2} \rightarrow \mathrm{Fe}_{\mathrm{m}} \mathrm{O}_{\mathrm{n}+1}+\mathrm{CO}$

$\mathrm{Fe}_{\mathrm{m}} \mathrm{O}_{\mathrm{n}+1}+\mathrm{C} \rightarrow \mathrm{Fe}_{\mathrm{m}} \mathrm{O}_{\mathrm{n}}+\mathrm{CO}$

\section{Kinetics analysis}

\subsection{Data analysis}

Carbon conversion could be obtained directly from the original weight loss vs. time or back calculated from gas production vs. time. In this study, the method of weight loss vs. time analysis would be adopted instead of the gas production analysis to ensure the certainty, when these two variables were continuously recorded.

The weight of BFS changed during the experiment. Therefore, the calculation method of carbon conversion was different between "pure" coal sample and coal with BFS sample. The carbon conversion of "pure" coal could be defined as followed:

$$
x(t)=\frac{w_{0}-w_{t}}{w_{0}-w_{\text {ash }}} \times 100 \%
$$

where, $x(t)$ was the carbon conversion at any reaction time $t, \%$; $w_{0}$ was the initial mass of coal char, mg; $w_{t}$ was the instantaneous mass of coal char at any reaction time $t, \mathrm{mg} ; w_{\text {ash }}$ was the mass of ash in coal char, mg.

The carbon conversion of coal with BFS was expressed as followed:

$$
x(t)=\left[\left(\frac{w_{c 0}-w_{c t}}{w_{c 0}-w_{c \infty}}\right)-\left(\frac{w_{s 0}-w_{s t}}{w_{s 0}-w_{s \infty}}\right) \times \frac{m}{m+1}\right] \times(1+m) \times 100 \%
$$

where, $w_{c 0}$ was the initial mass of coal char and BFS, mg; $w_{c t}$ was the instantaneous 
mass of coal char and BFS at any reaction time $t, \mathrm{mg} ; w_{c \infty}$ was the final mass of coal char and BFS, mg; $w_{s 0}$ was the initial mass of BFS, mg; $w_{s t}$ was the instantaneous mass of BFS at any reaction time $t, \mathrm{mg} ; w_{s \infty}$ was the final mass of BFS, mg; $m$ was the ratio of BFS to coal char.

For the particular gas-solid reaction system, the rate of steam gasification reaction with BFS as heat carrier could be obtained by the variation of carbon conversion and expressed as:

$r=\frac{d x}{d t}$

where, $r$ was the rate of gasification reaction, $\min ^{-1}$.

\subsection{Kinetic model}

In present experiment, the steam gasification of coal and ignition loss of BFS caused the weight loss of sample. The steam gasification reaction of coal was shown as Eq. (4).

$\mathrm{C}+\mathrm{H}_{2} \mathrm{O}(\mathrm{g})=\mathrm{CO}(\mathrm{g})+\mathrm{H}_{2}(\mathrm{~g}) \Delta \mathrm{H}_{r}=131 \mathrm{~kJ} \cdot \mathrm{mol}^{-1}$

A general rate law for the gas-solid reaction could be represented as the product of two independent functions of independent variables' temperature and conversion under isobaric considerations. According to Eq. (4), the reaction rate could be expressed as:

$r=\frac{d x}{d t}=k\left(T, P_{\text {steam }}\right) f(x)$

where, $k$ was the reaction rate constant of coal gasification; $P_{\text {steam }}$ was the reactant gas concentration; $f(x)$ was the reasonable model related to the reaction mechanism. 
Solving the first-order differential of Eq. (5), the gasification reaction time was a constant for a particular conversion:

$\int_{0}^{x_{1}} \frac{d x}{f(x)}=G(x)=\int_{0}^{t_{1}} k(T) d t$

$G(x)=k(T) t$

where, $G(x)$ was the mechanism function. The linear relationship between $G(x)$ and $t$ could be calculated by least square method and compared with the correlation coefficient $\left(R^{2}\right)$. We could get the most appropriate mechanism function $f(x)$ by this method. The most common kinetic models had been developed by many researchers to describe the variation of the pore structure during the reaction [29, 36-38], as shown in Table 3.

Table 3 Differential and integral expressions of common gas-solid reaction mechanism functions

\begin{tabular}{cccc}
\hline Code & Reaction model & Differential $f(x)$ & Integral $G(x)$ \\
\hline $\mathrm{A}_{\mathrm{m}}$ & Volumetric model & $m(1-x)[-\ln (1-x)]]_{m}^{m-1}$ & {$[-\ln (1-x)]^{\frac{1}{n}}$} \\
$\mathrm{~A}_{1}$ & $\mathrm{~m}=1$ & $1-x$ & $-\ln (1-x)$ \\
$\mathrm{A}_{2}$ & $\mathrm{~m}=2$ & $2(1-x)[-\ln (1-x)]^{1 / 2}$ & {$[-\ln (1-x)]^{1 / 2}$} \\
$\mathrm{~A}_{3}$ & $\mathrm{~m}=3$ & $3(1-x)[-\ln (1-x)]^{2 / 3}$ & {$[-\ln (1-x)]^{1 / 3}$} \\
$\mathrm{~A}_{4}$ & $\mathrm{~m}=4$ & $4(1-x)[-\ln (1-x)]^{1 / 4}$ & {$[-\ln (1-x)]^{1 / 4}$} \\
\hline $\mathrm{R}_{\mathrm{m}}$ & Shrinking core model & $m(1-x)^{m-1}$ & $1-(1-x)_{m}^{\frac{1}{m}}$ \\
$\mathrm{R}_{1 / 2}$ & $\mathrm{~m}=1 / 2$ & $(1 / 2)(1-x)^{-1}$ & $1-(1-x)^{2}$ \\
$\mathrm{R}_{1 / 3}$ & $\mathrm{~m}=1 / 3$ & $(1 / 3)(1-x)^{-2}$ & $1-(1-x)^{3}$ \\
\hline
\end{tabular}




\begin{tabular}{|c|c|c|c|}
\hline $\mathrm{R}_{1 / 4}$ & $\mathrm{~m}=1 / 4$ & $(1 / 4)(1-x)^{-3}$ & $1-(1-x)^{4}$ \\
\hline $\mathrm{R}_{2}$ & $\mathrm{~m}=2$ & $2(1-x)^{1 / 2}$ & $1-(1-x)^{1 / 2}$ \\
\hline $\mathrm{R}_{3}$ & $\mathrm{~m}=3$ & $3(1-x)^{2 / 3}$ & $1-(1-x)^{1 / 3}$ \\
\hline $\mathrm{D}_{\mathrm{m}}$ & Diffusion model & & \\
\hline $\mathrm{D}_{1}$ & Dimensional diffusion & $1 / 2 x^{-1}$ & $x^{2}$ \\
\hline $\mathrm{D}_{2}$ & Two- dimensional diffusion & {$[-\ln (1-x)]^{-1}$} & $x+(1-x) \ln (1-x)$ \\
\hline $\mathrm{D}_{3}$ & Three- dimensional diffusion & $(3 / 2)(1-x)^{2 / 3}\left[1-(1-x)^{1 / 3}\right]^{-1}$ & {$\left[1-(1-x)^{1 / 3}\right]^{2}$} \\
\hline $\mathrm{D}_{4}$ & Three- dimensional diffusion & $(3 / 2)\left[(1-x)^{-1 / 3}-1\right]^{-1}$ & $1-2 / 3 x-(1-x)^{2 / 3}$ \\
\hline $\mathrm{D}_{5}$ & 3-D (Anti-Jander) & $(3 / 2)(1+x)^{2 / 3}\left[(1+x)^{1 / 3}-1\right]^{-1}$ & {$\left[(1+x)^{1 / 3}-1\right]^{2}$} \\
\hline $\mathrm{D}_{6}$ & 3-D (ZLT) & $(3 / 2)(1-x)^{4 / 3}\left[(1-x)^{-1 / 3}-1\right]^{-1}$ & {$\left[(1-x)^{-1 / 3}-1\right]^{2}$} \\
\hline $\mathrm{D}_{7}$ & 3-D (Jander) & $6(1-x)^{2 / 3}\left[1-(1-x)^{1 / 3}\right]^{1 / 2}$ & {$\left[1-(1-x)^{1 / 3}\right]^{1 / 2}$} \\
\hline $\mathrm{D}_{8}$ & 2-D (Jander) & $(1-x)^{1 / 2}\left[1-(1-x)^{1 / 2}\right]^{-1}$ & {$\left[1-(1-x)^{1 / 2}\right]^{2}$} \\
\hline $\mathrm{C}_{\mathrm{n}}$ & Chemical reaction model & $(1-x)^{n}$ & $\frac{1-(1-\mathrm{x})^{1-n}}{1-n}$ \\
\hline $\mathrm{C}_{1}$ & Reaction order: $\mathrm{n}=2$ & $(1-x)^{2}$ & $(1-x)^{-1}-1$ \\
\hline $\mathrm{C}_{2}$ & Reaction order: $n=3 / 2$ & $2(1-x)^{3 / 2}$ & $(1-x)^{-1 / 2}-1$ \\
\hline
\end{tabular}

The constant of gasification reaction rate was dependent on reaction temperature and could be expressed with the Arrhenius equation as follow:

$k(T)=k_{0} \exp \left(-\frac{E_{a}}{R T}\right)$

where, $E_{a}$ was the activation energy, $\mathrm{kJ} \cdot \mathrm{mol}^{-1} ; k_{0}$ was the pre-exponential factor, $\mathrm{min}^{-1}$;

$T$ was the absolute temperature, $\mathrm{K}$. 
By taking the logarithm of Eq. (8), Eq. (9) could be obtained:

$\ln k=\ln k_{0}-\frac{E_{a}}{R} \times \frac{1}{T}$

In this work, linearized or linear regression of logarithm expression was used to obtain $E_{a}$ and $k_{0}$, which were estimated through the correlation of data at different reaction temperatures in an alternative form of Arrhenius equation.

\section{Results and discussions}

\subsection{Effect of gasification reaction temperature}

To explore the effect of reaction temperature, experiments were performed at: 1573

$\mathrm{K}, 1623 \mathrm{~K}$ and $1673 \mathrm{~K}$. The set of experiments (at different temperatures) repeated at various coal/slag ratios, while steam and $\mathrm{Ar}$ stream were constant. It helped to understand the effect of BFS on gasification reaction and determine kinetic parameters that would be described later.

As shown in Fig. 4(a), for all temperatures studied, carbon conversion was high during the first $20 \mathrm{~min}$ and then gradually slowed down, and seemed to reach a plateau. It was because that during the reaction, the ash had covered the carbon particle surface and thus increased the diffusion resistance [39]. Although Fig. 4(b) and Fig. 4(c) indicated the carbon conversion of coal mixed with BFS, the same change rule was presented in Fig. 4(a). The results obtained were in good agreement with those of other investigators $[15,30,31,39,40]$. It also could be observed that the effect of gasification temperature on carbon conversion was very important, because 
both pyrolysis and steam gasification depended on temperature. Meanwhile, within the same reaction time, carbon conversion increased with temperature increasing, especially from $1573 \mathrm{~K}$ to $1623 \mathrm{~K}$. However, from $1623 \mathrm{~K}$ to $1673 \mathrm{~K}$, the trend was non-significant, since the carbonaceous materials were consumed in shorter time when the temperature rose to a certain degree [20].
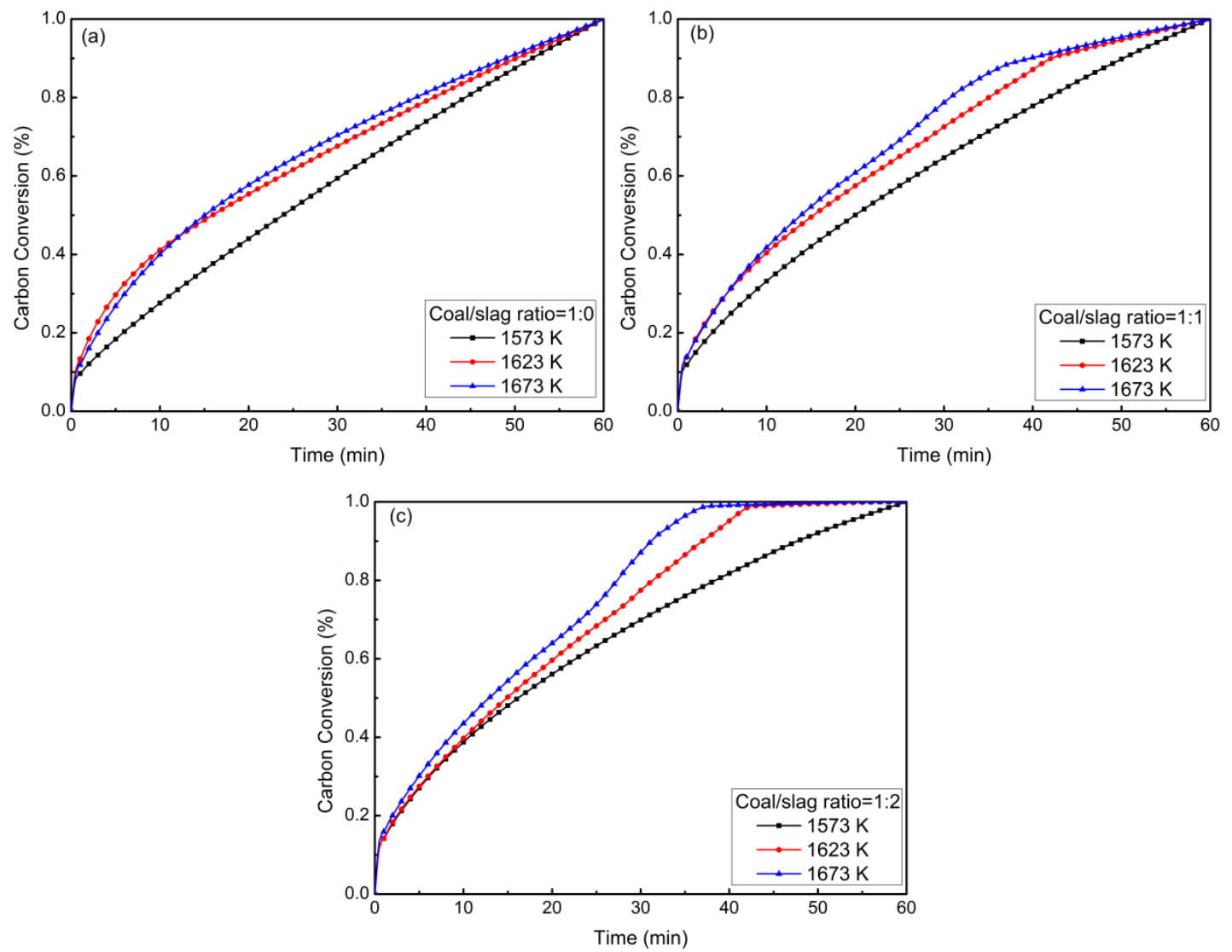

Fig. 4 Effect of temperature on carbon conversion during the gasification of FS coal at different coal $/$ slag ratios. (a). coal $/$ slag ratio $=1: 0,(b)$. coal $/$ slag ratio $=1: 1,(c)$. coal $/$ slag ratio $=1: 2$.

To further stretch the effect of temperature on gasification, the reactivity index was adopted. The reactivity index of gasification reaction $\left(R_{0.5}\right)$ was expressed as followed $R_{0.5}=\frac{0.5}{\tau_{0.5}}$ 
where, $\tau_{0.5}$ was the time necessary for carbon conversion reaching $50 \%$, min. Fig. 5 showed the variation of reactivity index with different reaction temperatures and coal/slag ratios. It could be observed that with the reaction temperature increasing, the reactivity index increased. For example, the reactivity index of steam gasification at $1673 \mathrm{~K}$ was about 1.6 times faster than that at $1573 \mathrm{~K}$, when the coal/slag ratio was 1:0. It also demonstrated the prominent effect of temperature on gasification reaction.

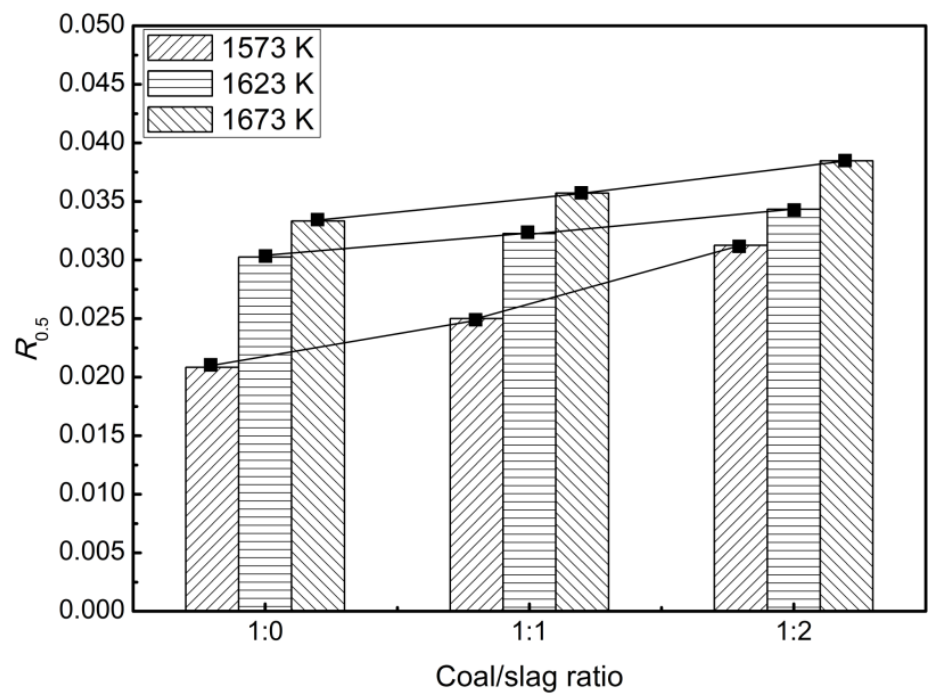

Fig. 5 Variation of reactivity index of steam gasification with changing reaction temperatures and coal/slag ratios

\subsection{Effect of blast furnace slag}

According to other works (Sun [18, 19, 41, 42], Luo [16, 17], Li [14, 43]), the BFS also had significant effect on gasification reaction. Fig. 5 showed the variation of reactivity index of coal gasification with different coal/slag ratios (1:0, 1:1 and 1:2) under the atmosphere of steam. It could be observed that the reactivity index of steam gasification increased with the ratio from 1:0 to $1: 2$ at the same temperature. For 
example, the reactivity index of coal was $0.020 \mathrm{~min}^{-1}$ with a coal/slag ratio of 1:0 at $1573 \mathrm{~K}$; however, the reactivity of coal was $0.033 \mathrm{~min}^{-1}$ with a coal/slag ratio of 1:2. Meanwhile, the time for completing carbon conversion decreased with BFS content increasing, as shown in Fig. 4. These illustrated that the BFS could act as an active catalyst in the process of steam gasification of coal and accelerate the gasification reaction rate. In $\mathrm{BFS}, \mathrm{Ca}, \mathrm{Mg}$ and $\mathrm{Fe}$ acted as catalyst and were found to be effective in gasification reaction.

Meanwhile, the catalytic mechanism of the iron was also explained detailedly, based on the Gibbs free energy for the reaction of iron compounds with production syngas by Duan et al [5]. Metal oxides could prevent the formation of stable chemical structures in hydrocarbons, speed up the degradation of hydrocarbons, and weaken the C-C bond $[44,45]$. In addition, the coal char particles were captured effectively by the molten slag surface when it was conveyed by gas stream [46-48]. Based on Shen's results $[47,48]$, the gasification reaction of char particles in the molten slag was promoted significantly. The section area of chars on the molten slag surface shrank obviously, and the time for the completing carbon conversion with slag was nearly half of that without slag. The heat transfer interactions between the slag and the char lead to high particle temperature on the molten slag.

\subsection{Kinetic mechanism of steam gasification}

After characterizing the whole gasification process, the kinetic mechanism of steam gasification could be further identified based on the TG-DTG curves. Various 
mechanism functions (as shown in Table 3) were used to fit these results. Based on Eq. (5), Eq. (6) and Eq. (7), the most appropriate mechanism function $f(x)$ could be obtained by analyzing the liner relationship between $G(x)$ and $t$.

In order to find an appropriate mechanism function to describe the steam gasification of coal, the correlation coefficient $\left(R^{2}\right)$ with the same coal/slag ratio and different temperatures was adopted in kinetic analysis. The $R^{2}$ for different coal/slag ratios and different temperatures were listed in the Table 4. From Table 4, the Diffusion model $\left(\mathrm{D}_{1}\right.$ model) was better than other reaction models when the coal/slag ratio was 1:0. However, when the steam gasification proceeded with BFS (coal/slag ratio=1:1 and 1:2), the most appropriate model was Shrinking core model $\left(\mathrm{R}_{2}\right.$ model). To authors' knowledge, there still was no kinetic analysis for steam gasification of coal with BFS as heat carrier. Therefore, it was necessary to establish a kinetic model for steam gasification of coal with BFS as heat carrier, so as to guide the industrial application of this technology. Meanwhile, the correctness of the kinetic model established could be verified by the available data for steam gasification reaction, which was presented by Gomez [30], Zhang [38] and Le [40].

Table 4 Comparison of the correlation coefficient $\left(R^{2}\right)$ using different mechanism functions

Code Steam gasification of FS coal, The coal/slag ratio

$1: 0$

$1: 1$

$1: 2$

Reaction temperature $(\mathrm{K})$ 


\begin{tabular}{lllllllll}
\hline 1573 & 1623 & 1673 & 1573 & 1623 & 1673 & 1573 & 1623 & 1673 \\
\hline \multicolumn{1}{c}{ Correlation coefficient $\left(R^{2}\right)$} \\
\hline
\end{tabular}

$\mathrm{A}_{\mathrm{m}} \quad$ Volumetric model, $\quad f(x)=m(1-x)[-\ln (1-x)]_{m}^{n-1}$

$\begin{array}{llllllllll}\mathrm{A}_{1} & 0.81 & 0.83 & 0.76 & 0.83 & 0.88 & 0.84 & 0.85 & 0.83 & 0.90 \\ & & & & & & & & & \\ \mathrm{~A}_{2} & 0.95 & 0.94 & 0.92 & 0.95 & 0.97 & 0.96 & 0.95 & 0.95 & 0.97 \\ & & & & & & & & & \\ \mathrm{~A}_{3} & 0.95 & 0.93 & 0.92 & 0.95 & 0.96 & 0.95 & 0.94 & 0.96 & 0.98 \\ & & & & & & & & & \\ \mathrm{~A}_{4} & 0.93 & 0.90 & 0.90 & 0.92 & 0.93 & 0.93 & 0.92 & 0.96 & 0.96\end{array}$

$\mathrm{R}_{\mathrm{m}} \quad$ Shrinking core model, $f(x)=m(1-x)^{\frac{m-1}{m}}$

\begin{tabular}{|c|c|c|c|c|c|c|c|c|c|}
\hline $\mathrm{R}_{1 / 2}$ & 0.88 & 0.77 & 0.74 & 0.83 & 0.75 & 0.71 & 0.77 & 0.73 & 0.67 \\
\hline $\mathrm{R}_{1 / 3}$ & 0.75 & 0.58 & 0.56 & 0.68 & 0.57 & 0.53 & 0.60 & 0.56 & 0.50 \\
\hline $\mathrm{R}_{1 / 4}$ & 0.63 & 0.42 & 0.43 & 0.54 & 0.43 & 0.40 & 0.46 & 0.43 & 0.38 \\
\hline $\mathbf{R}_{2}$ & 0.97 & 0.98 & 0.98 & 0.98 & 0.99 & 0.99 & 0.98 & 0.98 & 0.95 \\
\hline $\mathrm{R}_{3}$ & 0.92 & 0.92 & 0.96 & 0.93 & 0.97 & 0.99 & 0.95 & 0.97 & 0.97 \\
\hline
\end{tabular}

$\begin{array}{llllllllll}\mathbf{D}_{1} & \mathbf{0 . 9 7} & \mathbf{0 . 9 9} & \mathbf{0 . 9 9} & 0.99 & 0.99 & 0.97 & 0.99 & 0.96 & 0.91\end{array}$

$\begin{array}{llllllllll}\mathrm{D}_{2} & 0.91 & 0.95 & 0.97 & 0.94 & 0.98 & 0.99 & 0.97 & 0.95 & 0.93\end{array}$

$\begin{array}{llllllllll}\mathrm{D}_{3} & 0.67 & 0.69 & 0.79 & 0.72 & 0.81 & 0.89 & 0.77 & 0.88 & 0.93\end{array}$

$\begin{array}{llllllllll}\mathrm{D}_{4} & 0.86 & 0.91 & 0.93 & 0.90 & 0.96 & 0.98 & 0.93 & 0.94 & 0.94\end{array}$

$\begin{array}{llllllllll}\mathrm{D}_{5} & 0.96 & 0.98 & 0.95 & 0.99 & 0.98 & 0.96 & 0.99 & 0.95 & 0.90\end{array}$

$\begin{array}{llllllllll}\mathrm{D}_{6} & 0.23 & 0.04 & 0.05 & 0.24 & 0.04 & 0.06 & 0.25 & 0.15 & 0.15\end{array}$ 


\begin{tabular}{|c|c|c|c|c|c|c|c|c|c|}
\hline $\mathrm{D}_{7}$ & 0.97 & 0.95 & 0.95 & 0.97 & 0.97 & 0.96 & 0.96 & 0.97 & 0.95 \\
\hline $\mathrm{D}_{8}$ & 0.82 & 0.88 & 0.90 & 0.86 & 0.94 & 0.96 & 0.89 & 0.93 & 0.94 \\
\hline $\mathrm{C}_{\mathrm{n}}$ & \multicolumn{9}{|c|}{ Chemical reaction model, $f(x)=(1-x)^{n}$} \\
\hline $\mathrm{C}_{1}$ & 0.19 & 0.00 & 0.03 & 0.19 & 0.00 & 0.03 & 0.19 & 0.08 & 0.06 \\
\hline $\mathrm{C}_{2}$ & 0.47 & 0.48 & 0.16 & 0.48 & 0.51 & 0.18 & 0.49 & 0.27 & 0.30 \\
\hline
\end{tabular}

Based on Table 4 and above analysis, the most appropriate mechanism function of steam gasification with or without BFS as heat carrier could be represented by the equation as followed:

$r=\frac{d x}{d t}=\frac{1}{2} k(T) x^{-1}$

(Steam gasification of coal without BFS as heat carrier)

$r=\frac{d x}{d t}=2 k(T)(1-x)^{\frac{1}{2}}$

(Steam gasification of coal with BFS as heat carrier)

Table 5 The equation of gasification reaction rate and the estimated values of kinetic parameters for steam gasification of FS coal with BFS as heat carrier and catalyst

\begin{tabular}{|c|c|c|c|}
\hline \multirow{2}{*}{ Gasification rate equation } & \multicolumn{3}{|c|}{$r=\frac{d x}{d t}=\frac{1}{2} k_{0}\left(-\frac{E_{a}}{R T}\right) x^{-1}$ without BFS } \\
\hline & $r=\frac{d x}{d t}=2 k_{0} \exp$ & $\left(-\frac{E_{a}}{R T}\right)(1-x)^{1 / 2}$ & with BFS \\
\hline $\mathrm{coal} / \mathrm{slag}$ ratio & $1: 0$ & $1: 1$ & $1: 2$ \\
\hline Activation energy, $E_{a}\left(\mathrm{~kJ} \cdot \mathrm{mol}^{-1}\right)$ & $63.68 \pm 12.57$ & $27.08 \pm 10.26$ & $21.64 \pm 12.35$ \\
\hline Pre-exponential factor, $k_{0}\left(\mathrm{~min}^{-1}\right)$ & 1.79 & $1.04 \mathrm{E}-01$ & $6.07 \mathrm{E}-02$ \\
\hline
\end{tabular}

Based on the established mechanism function of steam gasification with BFS as 
heat carrier, $E_{a}$ and $k_{0}$ could be obtained by Eq. (8) and Eq. (9). Overall, the reaction rate equation (including $E_{a}$ and $k_{0}$ ) of steam gasification with BFS as heat carrier was established, as shown in Table 5. It could be seen from Table 5, the $E_{a}$ decreased with the coal/slag ratio increasing. The $E_{a}$ of the steam gasification without BFS slag was three times higher than that with BFS slag (coal/slag ratio=1:2). The BFS could significantly improve the steam gasification and enhance the reaction rate. However, with the coal/slag ratio changing from $1: 1$ to $1: 2$, the activation energy slightly decreased from $27.08 \mathrm{~kJ} \cdot \mathrm{mol}^{-1}$ to $21.64 \mathrm{~kJ} \cdot \mathrm{mol}^{-1}$. It was because the catalyst had already existed with the coal/slag ratio of $1: 1$. The excess slag addition didn't change the coal gasification reaction significantly.

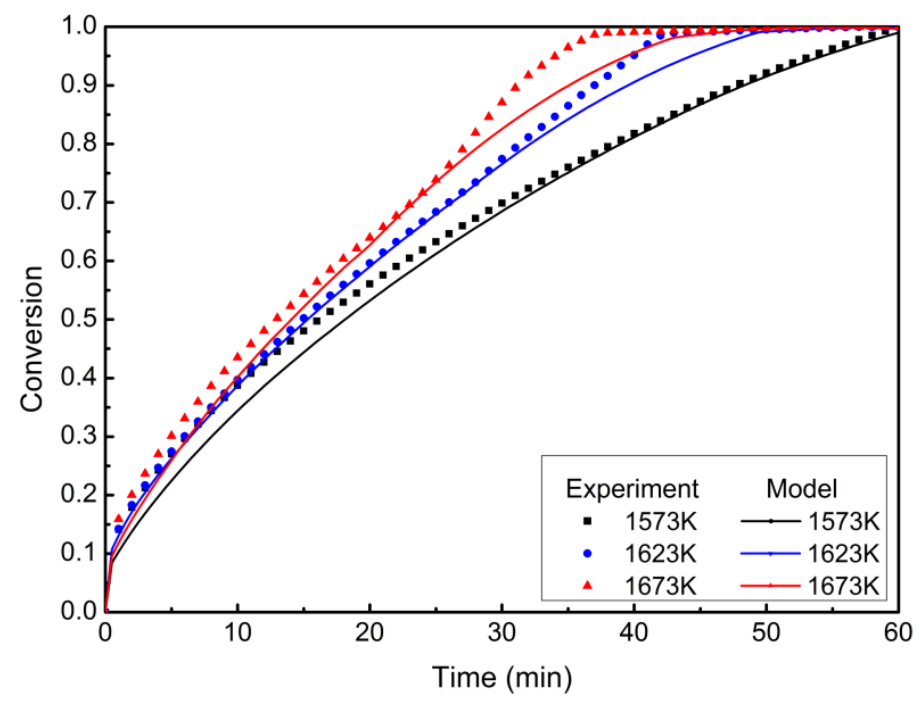

Fig. 6 The comparison between the model and experimental curves of FS coal under the coal/slag

\section{ratio of $1: 2$}

That was to say, the BFS could catalyst the coal gasification process and change the reaction activation energy, but the effect had a critical value. The changing value of 
$E_{a}$ obtained as a function of reaction degree across the temperature range suggested that the rate-controlling step changed during the entire reaction. The results obtained were consistent with Li $[12,15]$ and Gomez $[30,49]$. Take FS coal gasification using blast furnace slag as heat carrier under the coal/slag ratio of $1: 2$, the established model could descript the experimental data well, as shown in Fig. 6.

\section{Conclusions}

The kinetic study of steam gasification of FS coal with BFS as heat carrier was performed by isothermal thermo-gravimetry. The results demonstrated that BFS presented multiple roles on steam gasification, i.e., not only a heat carrier but also an effective catalyst. The carbon conversion and reactivity index of FS coal increased with reaction temperature increasing. The reactivity index of steam gasification at $1673 \mathrm{~K}$ was about 1.6 times faster than that at $1573 \mathrm{~K}$ when the coal/slag ratio was 1:0. But at higher temperature (above $1623 \mathrm{~K}$ ), the increasing trend of carbon conversion with temperature was non-significant. The reactivity index of coal increased from $0.020 \mathrm{~min}^{-1}$ to $0.033 \mathrm{~min}^{-1}$, when the coal/slag ratio changed from 1:0 to $1: 2$ at $1573 \mathrm{~K}$. Meanwhile, the time for completing carbon conversion decreased with increasing BFS content.

On the basis of experimental results, the predictive kinetic models (Diffusion model: $\mathrm{D}_{1}$ model (without BFS) and Shrinking core model: $\mathrm{R}_{2}$ model (with BFS)) were established. It was able to correctly predict the evolution of carbon conversion vs. 
time. From the slop of straight lines, we obtained the different activation energy with different coal/slag ratios: $63.68 \mathrm{~kJ} \cdot \mathrm{mol}^{-1}(\mathrm{coal} / \mathrm{slag}$ ratio $=1: 0), 27.08 \mathrm{~kJ} \cdot \mathrm{mol}^{-1}$ $(\mathrm{coal} / \mathrm{slag}$ raio $=1: 1)$, and $21.64 \mathrm{~kJ} \cdot \mathrm{mol}^{-1}(\mathrm{coal} / \mathrm{slag}$ ratio $=1: 2)$. Meanwhile the kinetic equation for steam gasification of FS coal with BFS as heat carrier was obtained.

\section{Nomenclature}

$x=$ the carbon conversion, $\%$;

$t=$ the reaction time, $\min$;

$x(t)=$ the carbon conversion at any reaction time $t, \%$;

$w_{0}=$ the initial mass of coal char, mg;

$w_{t}=$ the instantaneous mass of coal char at any reaction time $t, \mathrm{mg}$;

$w_{a s h}=$ the mass of ash in coal char, $\mathrm{mg}$;

$w_{c 0}=$ the initial mass of coal char and BFS, mg;

$w_{c t}=$ the instantaneous mass of coal char and BFS at any reaction time $t, \mathrm{mg}$;

$w_{c \infty}=$ the final mass of coal char and BFS, mg;

$w_{s 0}=$ the initial mass of BFS, mg;

$w_{s t}=$ the instantaneous mass of BFS at any reaction time $t, \mathrm{mg}$;

$w_{s \infty}=$ the final mass of BFS, $\mathrm{mg}$;

$m=$ the ratio of BFS to coal char;

$r=$ the rate of gasification reaction, $\min ^{-1}$; 
$k=$ the reaction rate constant of coal gasification;

$P_{\mathrm{CO}_{2}}=$ the reactant gas concentration;

$f(x)=$ the reasonable model related to the reaction mechanism;

$E_{a}=$ the activation energy, $\mathrm{kJ} \cdot \mathrm{mol}^{-1}$;

$k_{0}=$ the pre-exponential factor, $\min ^{-1}$;

$T=$ the absolute temperature, $\mathrm{K}$;

$G(x)=$ the mechanism function;

$R^{2}=$ the correlation coefficient

\section{Abbreviations}

$\mathrm{BFS}=$ Blast furnace slag

FS coal $=$ Fu Shun coal

Coal $/$ slag ratio $=$ Coal to blast furnace slag mass ratio

\section{Acknowledgements}

This research was supposed by The National Natural Science Foundation of China (51274066, 51304048), The National Science Foundation for Post-doctoral Scientists of China (2015M571322), The National Key Technologies R\&D Program of China (2013BAA03B03), The Fundamental Research Funds for the Central Universities (N130402019). We would very appreciate the reviewers' constructive comment on the manuscript. 


\section{References}

[1]. Mohammad S. H. K. Tushar, Animesh Dutta, Chunbao (Charles) Xu. Simulation and kinetic modeling of supercritical water gasification of biomass. International Journal of Hydrogen Energy 2015; 40: 4481-4493.

[2]. Acharya B, Dutta A, Basu P. Chemical-looping gasification of biomass for hydrogen-enriched gas production with in-process carbon dioxide capture. Energy \& Fuels 2009; 23(10): 5077-5083.

[3]. Khan Z, Inayat A, Yusup S, Ahmad MM. Kinetic parameters determination using optimization approach in integrated catalytic adsorption steam gasification for hydrogen production. International Journal of Hydrogen Energy 2015; 40: $8824-8832$.

[4]. Liu HX. Investigation of coal gasification using blast furnace molten slag as heat carrier. Energy Conversion 2004; 6: 41-43.

[5]. Duan WJ, Yu QB, Xie HQ, Qin Q, Zuo ZL. Thermodynamic analysis of hydrogen-rich gas generation from coal/steam gasification using blast furnace slag as heat carrier. International Journal of Hydrogen Energy 2014; 39: 11611-11619.

[6]. Duan WJ, Yu QB, Zuo ZL, Qin Q, Li P, Liu JX. The technological calculation for synergistic system of BF slag waste heat recovery and carbon resources reduction. Energy Conversion and Management 2014; 87: 185-190. 
[7]. Duan WJ, Yu QB, Wang K, Qin Q, Hou LM, Yao X, Wu TW. ASPEN Plus simulation of coal integrated gasification combined blast furnace slag waste heat recovery system. Energy Conversion and Management 2015; 100: 30-36.

[8]. Duan WJ, Li P, Lei W, Chen W, Yu QB, Wang K, Qin Q. Thermodynamic analysis of blast furnace slag waste heat-recovery system integrated with coal gasification. JOM 2015; 67(5): 1079-1084.

[9]. Duan WJ, Yu QB, Liu JX, Hou LM, Xie HQ, Wang K, Qin Q. Characterization of the hot blast furnace slag on coal gasification reaction. Applied Thermal Engineering 2016; 98: 936-943.

[10]. Duan WJ, Yu QB, Wu TW, Yang F, Qin Q. Experimental study on steam gasification of coal using molten blast furnace slag as heat carrier for producing hydrogen-enriched syngas. Energy Conversion and Management 2016; 117: 513-519.

[11]. Li P, Yu QB, Qin Q, Liu JX. Adaptability of coal gasification in molten blast furnace slag on coal samples and granularities. Energy \& Fuels 2011; 25(12): $5678-5682$.

[12]. Li P, Yu QB, Qin Q, Lei W. Kinetics of $\mathrm{CO}_{2}$ coal gasification in molten blast furnace slag. Industrial Engineering \& Chemical Research 2012; 51(49): $15872-15883$.

[13]. Liu JX, Yu QB, Li P, Du WY. Cold experiments on ligament formation for blast furnace slag granulation. Applied Thermal Engineering 2012; 40: 351-357. 
[14]. Li P, Yu QB, Xie HQ, Qin Q, Wang K. $\mathrm{CO}_{2}$ gasification rate analysis of Datong coal using slag granules as heat carrier for heat recovery from blast furnace slag by using a chemical reaction. Energy \& Fuels 2013; 27(8): 4810-4817.

[15]. Li P, Lei W, Wu B, Yu QB. $\mathrm{CO}_{2}$ gasification rate analysis of coal in molten blast furnace slag-For heat recovery from molten slag by using a chemical reaction. International Journal of Hydrogen Energy 2015; 40: 1607-1615.

[16]. Luo SY, Zhou YM, Yi CJ. Hydrogen-rich gas production from biomass catalytic gasification using hot blast furnace slag as heat carrier and catalyst in moving-bed reactor. International Journal of Hydrogen energy 2012; 37: 15081-15085.

[17]. Luo SY, Yi CJ, Zhou YM. Bio-oil production by pyrolysis of biomass using hot blast furnace slag. Renewable Energy 2013; 50: 373-377.

[18]. Sun YQ, Nakano J, Liu LL, Wang XD, Zhang ZT. Achieving waste to energy through sewage sludge gasification using hot slags: syngas production. Scientific Reports 2015; 5: 11436-11448.

[19]. Sun YQ, Zhang ZT, Liu LL, Wang XD. Integrated carbon dioxide/sludge gasification using waste heat from hot slags: Syngas production and sulfur dioxide fixation. Bioresource Technology 2015; 181: 174-182.

[20]. Skodras G, Nenes N, Zafeirious N. Low-rank coal- $\mathrm{CO}_{2}$ gasification: Experimental study, analysis of the kinetic parameters by Weibull distribution and compensation effect. Applied Thermal Engineering 2015; 74: 111-118.

[21]. Sedghkerdar MH, Mostafavi E, Mahinpey N. Sorbent enhanced hydrogen 28 
production from steam gasification of coal integrated with $\mathrm{CO}_{2}$ capture. International Journal of Hydrogen Energy 2014; 39: 17001-1708.

[22]. Jin H, Chen Y, Ge ZW, Liu SK, Ren CS, Guo LJ. Hydrogen production by Zhundong coal gasification in supercritical water. International Journal of Hydrogen Energy 2015; 40: 16096-16103.

[23]. Phuhiran C, Takarada T, Chaiklangmuang S. Hydrogen-rich gas from catalytic steam gasification of eucalyptus using nickel-loaded Thai brown coal char catalyst. International Journal of Hydrogen Energy 2014; 39: 3649-3656.

[24]. Kandasamy J, Iskender G, Elisa B. Kinetics of steam and $\mathrm{CO}_{2}$ gasification of high ash coal-char produced under various heating rates. Fuel 2015; 154: 370-379.

[25]. Jin H, Guo LJ, Guo J. Study on gasification kinetics of hydrogen production from lignite in supercritical water. International Journal of Hydrogen Energy 2015; 40: 7523-7529.

[26]. Chan FL, Umeki K, Tankasle A. Kinetic study of catalytic steam gasification of biomass by using reactive flash volatilisation. ChemCatChem 2015; 7: $1329-1337$.

[27]. Wang C, Dou BL, Chen HS. Renewable hydrogen production from steam reforming of glycerol by $\mathrm{Ni}-\mathrm{Cu}-\mathrm{Al}, \mathrm{Ni}-\mathrm{Cu}-\mathrm{Mg}, \mathrm{Ni}-\mathrm{Mg}$ catalysts. International Journal of Hydrogen Energy 2013; 38: 3562-3571.

[28]. Kim HS, Kudo S, Tahara K. Detailed kinetic analysis and modeling of steam 
gasification of char from Ca-Loaded Lignite. Energy \& Fuels 2013; 6617-6631.

[29]. Jang DH, Kim HT, Lee C, Kim SH. Kinetic analysis of catalytic coal gasification process in fixed bed condition using Aspen Plus. International Journal of Hydrogen Energy 2013; 38: 6021-6026.

[30]. Gomez A, Mahinpey N. Kinetic study of coal steam and $\mathrm{CO}_{2}$ gasification: A new method to reduce interparticle diffusion. Fuel 2015; 148: 160-167.

[31]. Silbermann R, Gomez A, Gates I, Mahinpey N. Kinetic studies of a novel $\mathrm{CO}_{2}$ gasification method using coal from deep unmineable seams. Industrial \& Engineering Chemistry Research 2013; 52(42): 14787-14797.

[32]. Gomez A, Silbermann R, Mahinpey N. A comprehensive experimental procedure for $\mathrm{CO}_{2}$ coal gasification: Is there really a maximum reaction rate? Applied Energy 2014; 124: 73-81.

[33]. Obara S, Morel J, Okada M, Kobayashi K. Study on the dynamic characteristics of an integrated coal gasification fuel cell combined cycle. International Journal of Hydrogen Energy 2015; 40: 14996-15011.

[34]. Jang DH, Yoon SP, Kim HT, Choi YC, Lee C. Simulation analysis of hybrid coal gasification according to various conditions in entrained-flow gasifier. International Journal of Hydrogen Energy 2015; 40: 2162-2172.

[35]. Duan WJ, Yu QB, Xie HQ, Liu JX, Wang K, Qin Q, Han ZC. Thermodynamic analysis of synergistic coal gasification using blast furnace slag as heat carrier. International Journal of Hydrogen Energy 2016; 41: 1502-1512. 
[36]. Sergey Vyazovkin, Burnham Alan K, Criado José M, Pérez-Maqueda Luis A, Popescu Crisan, Sbirrazzuoli Nicolas. ICTAC kinetic committee recommendations for performing kinetic computations on thermal analysis data. Thermochimica Acta 2011; 520: 1-19.

[37]. Ye DP, Agnew JB, Zhang DK. Gasification of a south Australian low-rank coal with carbon dioxide and steam: kinetics and reactivity studies. Fuel 1998; 77: 1209-1219.

[38]. Zhang L, Huang J, Fang Y, Wang Y. Gasification reactivity and kinetics of typical Chinese anthracite chars with steam and $\mathrm{CO}_{2}$. Energy \& Fuels 2006; 20(3): 1201-1210.

[39]. Guo WT, Xue QG, Liu YL, Guo ZC, She XF, Wang JS, Zhao QQ, An XW. Kinetic analysis of gasification reaction of coke with $\mathrm{CO}_{2}$ or $\mathrm{H}_{2} \mathrm{O}$. International Journal of Hydrogen Energy 2015; 40(39): 13306-13313.

[40]. Le CD, Kolaczkowski ST. Steam gasification of a refuse derived char: Reactivity and kinetics. Chemical Engineering Research and Design 2015; 102: 389-398.

[41]. Sun YQ, Zhang ZT, Seetharaman S, Liu LL, Wang XD. Characteristics of low temperature biomass gasification and syngas release behavior using hot slag. RSC Advances 2014; 4: 62105-62114.

[42]. Sun YQ, Zhang ZT, Liu LL, Wang XD. Two-stage high temperature sludge gasification using the waste heat from hot blast furnace slags. Bioresource 
Technology 2015; 198: 364-371.

[43]. Li P, Yu QB, Qin Q, Du WY. The effects of slag compositions on the coal gasification reaction in molten blast furnace slag. Energy Sources, Part A: Recovery Utilization, and Environment Effects 2014; 36: 73-79.

[44]. Rustamov VR, Abdullayev KM, Samedov EA. Biomass conversion to liquid fuel by two-stage thermochemical cycle. Energy Conversion and Management 1998; 39(9): 869-875.

[45]. Shen BX, Qin L. Study on MSW catalytic combustion by TGA. Energy Conversion and Management 2006; 47(11-12): 1429-1437.

[46]. Shimizu T, Tominaga H. A model of char capture by molten slag surface under high-temperature gasification conditions. Fuel 2006; 85: 170-178.

[47]. Shen ZJ, Liang QF, Xu JL, Zhang BB, Liu HF. In-suit experimental study of $\mathrm{CO}_{2}$ gasification of char particles on molten slag surface. Fuel 2015; 160: $560-567$.

[48]. Shen ZJ, Liang QF, Xu JL, Liu HF. In suit study on the formation mechanism of bubbles during the reaction of captured chars on molten slag surface. International Journal of Heat and Mass Transfer 2016; 95: 517-524.

[49]. Gomez A, Mahinpey N. A new method to calculate kinetic parameters independent of the kinetic model: Insights on $\mathrm{CO}_{2}$ and steam gasification. Chemical Engineering Research and Design 2015; 95: 346-357. 


\section{TABLE CAPTION}

Table 1 The proximate and ultimate analysis of FS coal sample

Table 2 The physical properties and chemical compositions of the BFS

Table 3 Differential and integral expressions of common gas-solid reaction mechanism functions

Table 4 Comparison of the correlation coefficient $\left(R^{2}\right)$ using different mechanism functions

Table 5 The equation of gasification reaction rate and the estimated values of kinetic parameters for steam gasification of FS coal with BFS as heat carrier and catalyst 


\section{FIGURE CAPTION}

Fig. 1 The schematic diagram of the thermo-gravimetric experimental apparatus

Fig. 2 The diagram of the thermo-gravimetric experimental procedure

Fig. 3 XRD results of the water quenched BFS

Fig. 4 Effect of temperature on carbon conversion during the gasification of FS coal at different coal $/$ slag ratios. (a). coal $/$ slag ratio $=1: 0,(b)$. coal $/$ slag ratio $=1: 1$, (c). coal $/$ slag ratio $=1: 2$

Fig. 5 Variation of reactivity index of steam gasification with changing reaction temperatures and coal/slag ratios

Fig. 6 The comparison between the model and experimental curves of FS coal under the coal/slag ratio of $1: 2$ 